\title{
ANALISIS PENGGUNAAN PREFABRICATED VERTICAL DRAINS (PVD) PADA TANAH LEMPUNG LUNAK YANG TERDAPAT LAPISAN LENSA
}

\author{
Andreyan Prasetio ${ }^{1}$ dan Aniek Prihatiningsih ${ }^{2}$ \\ ${ }^{1}$ Program Studi Sarjana Teknik Sipil, Universitas Tarumanagara, Jl. Letjen S. Parman No.1 Jakarta \\ andreyan.325150125@stu.untar.ac.id \\ ${ }^{2}$ Program Studi Sarjana Teknik Sipil, Universitas Tarumanagara, Jl. Letjen S. Parman No.1 Jakarta \\ aniekp@ft.untar.ac.id
}

Masuk: 17-01-2020, revisi: 16-02-2020, diterima untuk diterbitkan: 18-02-2020

\begin{abstract}
Problem that often occurs in soft cohesive soils is settlement caused by consolidation process. If construction activities doing when the soils has not been consolidated, settlement can occur. To accelerate the consolidation process, soil improvement are usually do, one method of soil improvement to accelarate the consolidation process is vertical drain using prefabricated vertical drains (PVD). The soft soil layers in the field are not always continuous, sometimes found soft soil layers that have a lens layer. In this study, will discuss about the settlement and consolidation time of soft soil layers that have a lens layer which has been improved by PVD with 1 meter distance. Infrastructure that stand on a location that is installed by PVD is taxiway and loading by Airbus A380 aircraft of $18,22 \mathrm{ton} / \mathrm{m}^{2}$. Analysis using the 1 dimensional consolidation theory of Terzaghi. For PVD installation to a depth of 50 meters, preloading settlement of 234,80 cm with a consolidation time of 2260 days for the square pattern PVD and 1918 days for triangle pattern PVD. Post loading settlement for PVD installation depth of 50 meters by 2,50 $\mathrm{cm}$.
\end{abstract}

Keywords : cohesive soils, consolidation, time factor, prefabricated vertical drain (PVD), lens layer.

\begin{abstract}
ABSTRAK
Masalah yang sering terjadi pada tanah kohesif dan lunak adalah penurunan yang disebabkan proses konsolidasi. Penurunan dapat menyebabkan keretakan pada struktur konstruksi yang berada di atasnya. Jika suatu kegiatan konstruksi dilakukan saat tanah belum terkonsolidasi, maka konstruksi tersebut dapat mengalami penurunan.. Untuk mempercepat proses konsolidasi biasanya dilakukan perbaikan tanah, salah satu metode perbaikan tanah untuk mempercepat proses konsolidasi yaitu vertical drain dengan menggunakan prefabricated vertical drains (PVD). Lapisan tanah lunak yang terdapat di lapangan tidak selalu kontinu, terkadang ditemukan lapisan tanah lunak yang terdapat lapisan lensa. Pada penelitian ini, penulis akan membahas mengenai waktu konsolidasi yang dibutuhkan oleh lapisan tanah kohesif dan lunak yang terdapat lapisan lensa yang telah diperbaiki dengan menggunakan PVD berjarak 1 meter. Infrastruktur yang berdiri di atas lokasi yang dipasang PVD berupa taxiway dengan beban berupa pesawat Airbus A380 sebesar 18,22 ton $/ \mathrm{m}^{2}$. Analisis dilakukan menggunakan teori konsolidasi 1 dimensi Terzaghi. Untuk pemasangan PVD hingga kedalaman 50 meter diperoleh penurunan pra pembebanan sebesar $234,80 \mathrm{~cm}$ dengan waktu konsolidasi selama 2260 hari untuk pemasangan PVD pola persegi dan selama 1918 hari untuk pola segitiga . Penurunan pasca pembebanan untuk pemasangan PVD hingga kedalaman 50 meter sebesar $2,5 \mathrm{~cm}$.
\end{abstract}

Kata kunci : tanah kohesif, konsolidasi, faktor waktu, prefabricated vertical drain (PVD), lapisan lensa.

\section{PENDAHULUAN}

Pembangunan infrastruktur sedang giat dilakukan oleh pemerintah, salah satunya adalah bandar udara. Indonesia terdiri dari banyak pulau, oleh karena itu pembangunan bandar udara dilakukan untuk meningkatkan aksesibilitas penduduk dan juga melancarkan kegiatan distribusi barang. Pada pembangunan bandar udara terutama landasan pacu, hal yang harus diperhatikan adalah beban konstruksi yang berat mencapai 18,22 ton/ $\mathrm{m}^{2}$ harus dapat ditahan oleh daya dukung tanah pada lokasi konstruksi tersebut.

Hal yang menjadi pertimbangan pada suatu kegiatan konstruksi pada tanah kohesif lunak adalah masalah penurunan konsolidasi. Jika kegiatan konstruksi tetap dilakukan pada saat tanah belum terkonsolidasi sempurna, maka 
konstruksi yang berada di atas tanah tersebut akan mengalami penurunan dan terjadi retak. Apabila kegiatan konstruksi baru dimulai saat tanah telah terkonsolidasi, maka akan memerlukan waktu yang sangat lama yaitu bisa mencapai lebih dari 1200 hari. Untuk mempercepat proses konsolidasi dan memperkecil kemungkinan penurunan di masa mendatang, biasanya dilakukan perbaikan tanah terutama pada tanah lempung lunak dan jenuh air yaitu dengan metode prefabricated vertical drains (PVD) yang berupa material yang berbentuk pipih terdiri dari saluran inti drainase yang diselimuti oleh geotekstil yang berfungsi sebagai filter (ptgsi.com) bertujuan untuk mempercepat pengeluaran air pori sehingga konsolidasi terjadi lebih cepat. Penggunaan PVD biasanya digabungkan dengan preloading berupa timbunan tanah dengan tinggi tertentu. PVD umumnya dipasang pada lapisan tanah lunak, namun tidak selamanya kondisi yang ditemukan di lapangan lapisan tanah lunak bersifat kontinu, terkadang ditemukan kondisi dimana terdapat lapisan lensa yaitu lapisan tanah keras yang relatif tipis diantara lapisan tanah lunak.

Perhitungan penurunan pada penelitian ini menggunakan teori konsolidasi 1 dimensi Terzaghi. Untuk membantu proses perhitungan besar dan waktu penurunan yang terjadi digunakan spreadsheet. Pada penelitian ini digunakan jarak antar PVD sebesar 1 meter dengan menggunakan pola kotak. Infrastruktur yang berdiri di atas lokasi yang dipasang PVD berupa taxiway. Derajat konsolidasi horizontal yang digunakan sebesar 60\% dengan hasil penelitian berupa waktu konsolidasi yang dibutuhkan dan besar penurunan yang terjadi.

Penelitian ini dilakukan untuk mengetahui perbandingan kinerja antara PVD pola persegi dengan pola segitiga untuk mempercepat waktu penurunan. Selain itu juga untuk mengetahui waktu konsolidasi yang dibutuhkan oleh lapisan tanah kohesif dan lunak yang terdapat lapisan lensa untuk masing-masing pola PVD yang digunakan serta mengetahui besar penurunan yang terjadi setelah dipasang PVD.

\section{Prefabricated vertical drains (PVD)}

Prefabricated vertical drains (PVD) adalah lembaran plastik untuk drainase vertikal yang panjang dan berkantung yang merupakan kombinasi bahan inti (core) polypropilene berkekuatan mekanik tinggi dan dibungkus oleh bahan geotekstil seperti pada Gambar 1 .

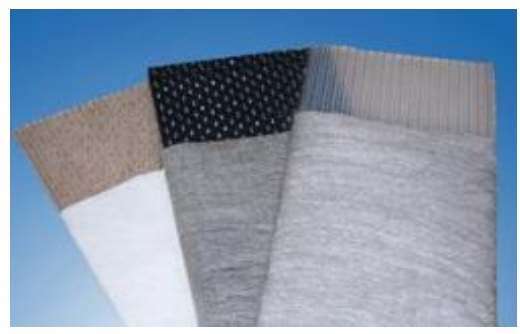

Gambar 1. Prefabricated vertical drain (Sumber: ptgsi.com)

Tujuan dari penggunaan drainase vertikal adalah untuk mempercepat proses penurunan konsolidasi dengan cara mempercepat aliran keluar air pori. (Haussmann, 1990). Pada konsolidasi normal, aliran air pori yang keluar dari tanah sangat lambat dikarenakan permeabilitas yang bekerja hanya pada arah vertikal. Pada penggunaan drainase vertikal, selain permeabilitas arah vertikal juga berkerja permeabilitas arah horizontal yang menuju ke arah drainase vertikal seperti pada Gambar 2.

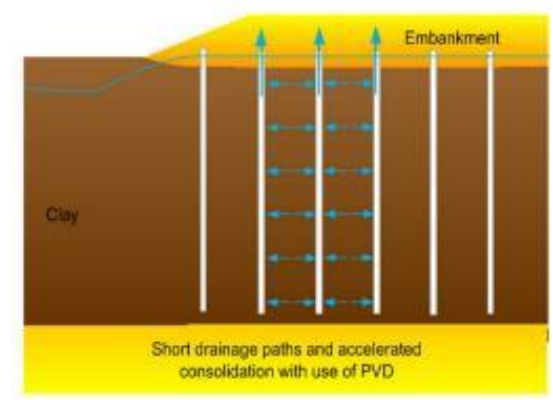

Gambar 2. Skema aliran air pada penggunaan drainase vertikal (Sumber: cofra.com) 
Pada Gambar 3. menunjukkan skema dari diameter pengaruh PVD yang merupakan fungsi dari jarak antar yang juga dipengaruhi oleh pola pemasangan PVD dinyatakan dalam persamaan berikut (Aspar dan Fitriani, 2016):

$$
\begin{array}{ll}
\mathrm{D}_{\mathrm{e}}=1,05 \mathrm{~S} & \text { (pola segitiga) } \\
\mathrm{D}_{\mathrm{e}}=1,128 \mathrm{~S} & \text { (pola kotak) }
\end{array}
$$
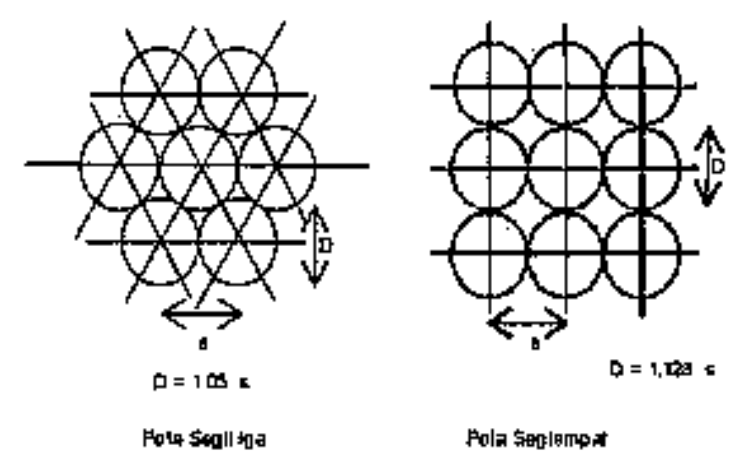

Gambar 3. Pola pemasangan prefabricated vertical drains (Sumber: pandu-equator.com)

Parameter faktor jarak drainase $(\mu)$ dapat ditunjukkan oleh persamaan dari (Hansbo, 1981):

$$
\begin{aligned}
& \mu=\ln \frac{n}{s}+\frac{k_{h}}{k_{s}} \ln (\mathrm{s})-\frac{3}{4}+\pi \frac{2 l^{2} k_{h}}{3 q_{w}} \\
& \mathrm{~s}=\frac{d_{s}}{d_{w}} \\
& \mathrm{n}=\frac{D_{e}}{d_{w}}
\end{aligned}
$$

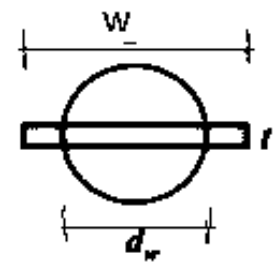

Gambar 4. Diameter ekivalen vertical drain (Sumber: Saputro et al.)

Skema dari diameter ekivalen vertical drain ditunjukkan pada Gambar 4. yang mengasumsikan ukuran PVD yang berbentuk pipih menjadi lingkaran dengan diamteter tertentu. Diameter ekivalen vertical drain (dw) ditentukan dari persamaan berikut:

$$
\mathrm{d}_{\mathrm{w}}=0,5 \mathrm{w}+0,7 \mathrm{t} \quad(\text { Long dan Covo, 1994) }
$$

\section{Smear Zone}

Ketika prefabricated vertical drains (PVD) dipasang pada tanah lempung lunak menggunakan mandrel, zona yang dirusak disekitar mandrel disebut smear effect. Diameter ekivalen smear zone dapat ditentukan dari diameter ekivalen PVD dengan koefisien pengali yang ditentukan dari persamaan berikut:

$$
\mathrm{d}_{\mathrm{s}}=(1,5 \text { sampai } 3) \mathrm{d}_{\mathrm{w}} \quad(\text { Hansbo, 1979) }
$$

$\mathrm{d}_{\mathrm{s}}=$ diameter ekivalen smear zone, $\mathrm{d}_{\mathrm{w}}=$ diameter prefabricated vertical drains $(\mathrm{m})$ 


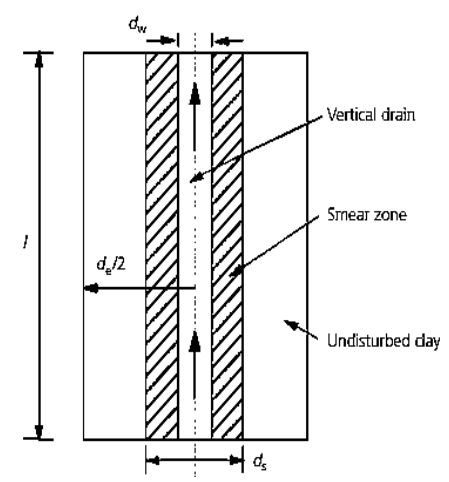

Gambar 5. Vertical drain dengan smear zone (Sumber: Chu et al., 2014)

Pada Gambar 5., daerah yang diarsir adalah smear zone yang timbul akibat tanah lempung yang dirusak oleh mandrel yang menyebabkan permeabilitas pada smear zone berkurang secara signifikan (Shen et al., 2005).

\section{Kapasitas pengaliran}

Merupakan kemampuan dari prefabricated vertical drains (PVD) untuk mengalirkan air dalam satu tahun. Kapasitas pengaliran di lapangan jauh lebih kecil dari yang diberikan oleh pabrikan. Nilai kapasitas pengaliran berkisar antara $100-500 \mathrm{~m}^{3} /$ tahun. Berdasarkan hasil pengujian, nilai kapasitas pengaliran beberapa produk PVD dapat lebih rendah berkisar antara $5-100 \mathrm{~m}^{3} /$ tahun di bawah tekanan batas dan gradien hidrolik rendah (Holtz et al., 1991).

\section{Preloading}

Preloading menambah daya dukung dan mengurangi kompresibilitas dari tanah lunak. Preloading membuat tanah pasiran lepas menjadi padat, ataupun membuat tanah lempung dan lanau terkonsolidasi (Hausmann, 1990). Cara melakukan preloading adalah dengan membuat timbunan tanah sementara pada lokasi konstruksi yang direncanakan. Meskipun dapat dilakukan pada semua jenis tanah, preloading lebih efektif diterapkan pada tanah kohesif lunak.

Beban total preloading berupa timbunan tanah yang diaplikasikan ke tanah asli harus lebih besar atau sama dengan 1,3 kali beban yang direncanakan pada kondisi layan bila efek gaya angkat (bouyancy effect) yang diterima beban timbunan pada saat proses preloading berlangsung tidak diperhitungkan. Sedangkan jika efek gaya angkat (bouyancy effect) yang diterima beban timbunan pada saat proses preloading diperhitungkan, maka beban total preloading berupa timbunan tanah yang diaplikasikan ke tanah asli harus lebih besar atau sama dengan 1,2 kali beban yang direncanakan pada kondisi layan (SNI 8460:2017).

\section{Permeabilitas}

Suatu bahan dikatakan permeabel jika mengandung pori-pori yang menerus. Permeabilitas tanah dipengaruhi oleh beberapa faktor antara lain viskositas cairan, distribusi ukuran pori, distribusi ukuran butir, angka pori, dan derajat kejenuhan dari tanah (Das, 1995). Pada tabel berikut dapat dilihat beberapa jenis tanah dan koefisien permeabilitasnya.

Tabel 1. Koefisien permeabilitas tiap jenis tanah (Das, 1995)

\begin{tabular}{lc}
\hline \multicolumn{1}{c}{ Jenis Tanah } & $\begin{array}{c}\text { Koefisien } \\
\text { Permeabilitas (cm/detik) }\end{array}$ \\
\hline Kerikil bersih & $1,0-100$ \\
Pasir kasar & $1,0-0,01$ \\
Pasir halus & $0,01-0,001$ \\
Lanau & $0,001-0,00001$ \\
Lempung & kurang dari 0,000001 \\
\hline (Sumber: Das, 1995)
\end{tabular}

\section{Penurunan konsolidasi}

Penurunan konsolidasi merupakan hasil dari perubahan volume tanah jenuh air sebagai akibat dari keluarnya air yang menempati pori-pori tanah. Pada saat tanah diberi penambahan beban maka tekanan air pori akan meningkat secara mendadak, pada tanah berpasir yang permeabilitas tinggi air pori akan keluar dengan cepat dan penurunan 
terjadi dengan segera. Namun pada tanah lempung, nilai permeabilitas rendah dan dibutuhkan waktu yang lama untuk mengalirkan air pori keluar sehingga penurunan yang terjadi lebih lambat karena koefisien permeabilitas lempung sangat kecil yang bernilai hanya sekitar $1 \times 10^{-6} \mathrm{~cm} /$ detik dibandingkan dengan koefisien permeabilitas pasir yang mencapai $1 \mathrm{~cm} /$ detik. Untuk tanah lempung lunak perubahan volume yang disebabkan oleh keluarnya air pori (konsolidasi) akan terjadi setelah penurunan segera terjadi. Pada umumnya, penurunan konsolidasi lebih besar dan dibutuhkan waktu yang lebih lama dibandingkan dengan penurunan segera (Das, 1995).

Berdasarkan teori konsolidasi satu dimensi oleh Terzaghi, penurunan yang terjadi ditunjukkan oleh persamaan berikut:

$$
\mathrm{S}_{\mathrm{c}}=\mathrm{H}\left[\mathrm{R}_{\mathrm{R}} \cdot \log \frac{\sigma^{\prime} v m}{\sigma^{\prime} v o}+\mathrm{C}_{\mathrm{R}} \cdot \log \frac{\sigma^{\prime}{ }_{v o}+\Delta \sigma_{v}}{\sigma^{\prime} v m}\right]
$$

Rasio kompresi dapat ditentukan dari indeks pemampatan dan angka pori awal menggunakan persamaan berikut:

$$
\mathrm{C}_{\mathrm{R}}=\frac{C_{C}}{1+e_{0}}
$$

Dari rasio kompresi yang diperoleh dari persamaan (9) dapat dihitung rasio rekompresi dengan menggunakan persamaan berikut:

$$
\mathrm{R}_{\mathrm{R}}=\frac{C_{R}}{1+e_{0}}
$$

$\mathrm{S}_{\mathrm{c}}=$ penurunan primer, $\mathrm{H}=$ tebal lapisan terkonsolidasi, $\mathrm{C}_{\mathrm{R}}=$ rasio kompresi, $\mathrm{R}_{\mathrm{R}}=$ rasio rekompresi, $\sigma^{\prime}{ }_{v m}=$ tekanan prakompresi, $\sigma_{v o}^{\prime}=$ tekanan efektif overburdeen, $\Delta \sigma_{v}=$ penambahan beban

\section{Indeks pemampatan}

Indeks pemampatan digunakan untuk menghitung besarnya penurunan yang terjadi di lapangan sebagai akibat dari konsolidasi. Persamaan empiris untuk menghitung indeks pemampatan dari parameter batas cair (liquid limit) disarankan oleh Terzaghi dan Peck (1967):

Untuk lempung yang struktur tanahnya tidak terganggu (undistubed):

Untuk lempung yang dibentuk kembali (remolded):

$$
\mathrm{C}_{\mathrm{c}}=0,009(\mathrm{LL}-10)
$$

$$
\mathrm{C}_{\mathrm{c}}=0,007(\mathrm{LL}-10)
$$

Perumusan lain untuk menghitung indeks pemampatan untuk macam-macam jenis lempung tersedia pada Tabel 2 .

Tabel 2. Persamaan indeks pemampatan

\begin{tabular}{lll}
\hline Persamaan & Acuan & Kondisi Pemakaian \\
\hline $\mathrm{C}_{\mathrm{c}}=0,007(\mathrm{LL}-7)$ & Skempton & $\begin{array}{l}\text { Lempung yang terbentuk kembali (remolded }) \\
\text { Lempung Chicago }\end{array}$ \\
$\mathrm{C}_{\mathrm{c}}=0,01 \mathrm{~W}_{\mathrm{N}}$ & Nishida & $\begin{array}{l}\text { Semua Lempung } \\
\text { Tanah kohesif anorganik, lanau, lempung } \\
\mathrm{C}_{\mathrm{c}}=1,15\left(\mathrm{e}_{0}-0,27\right)\end{array}$ \\
$\mathrm{C}_{\mathrm{c}}=0,30\left(\mathrm{e}_{0}-0,27\right)$ & Hough & $\begin{array}{l}\text { berlanau } \\
\text { Tanah organik, gambut, lanau organik, dan }\end{array}$ \\
$\mathrm{C}_{\mathrm{c}}=0,0115 \mathrm{~W}_{\mathrm{N}}$ & & lempung \\
$\mathrm{C}_{\mathrm{c}}=0,0046(\mathrm{LL}-9)$ & Lempung Brazilia \\
$\mathrm{C}_{\mathrm{c}}=0,75\left(\mathrm{e}_{0}-0,5\right)$ & Tanah dengan plastisitas rendah \\
$\mathrm{C}_{\mathrm{c}}=0,208 \mathrm{e}_{0}+0,0083$ & & Lempung Chicago \\
$\mathrm{C}_{\mathrm{c}}=0,156 \mathrm{e}_{0}+0,0107$ & & Semua Lempung \\
\hline $\mathrm{C}_{\mathrm{c}}=$ indeks pemampatan, $\mathrm{LL}=$ batas cair, $\mathrm{e}_{0}=$ angka pori awal, $\mathrm{W}_{\mathrm{N}}=$ kadar air tanah di lapangan &
\end{tabular}

\section{Indeks pemuaian}

Indeks pemuaian bernilai lebih kecil daripada indeks pemampatan. Indeks pemuaian dapat ditentukan dari hasil laboratorium atau dapat ditentukan dari persamaan berikut (Terzaghi dan Peck, 1967):

$$
\mathrm{C}_{\mathrm{s}}=\frac{1}{5} \text { sampai } \frac{1}{10} \mathrm{C}_{\mathrm{c}}
$$

$\mathrm{C}_{\mathrm{s}}=$ indeks pemuaian 


\section{Derajat konsolidasi}

Persamaan yang diberikan oleh Baron (1948) yang berhubungan dengan konsolidasi arah horizontal yang terdiri dari derajat konsolidasi horizontal, faktor waktu konsolidasi horizontal, dan koefisien konsolidasi horizontal sebagai berikut:

$$
\begin{aligned}
\mathrm{U}_{\mathrm{h}} & =1-\exp \left(\frac{-8 T_{h}}{F}\right) \\
\mathrm{T}_{\mathrm{h}} & =\frac{C_{h} \cdot T}{D e^{2}} \\
\mathrm{C}_{\mathrm{h}} & =\frac{-D e^{2} \cdot \mu \cdot \ln \left(1-U_{h}\right)}{8 T}
\end{aligned}
$$

Sedangkan untuk menghitung derajat konsolidasi vertikal dan faktor waktu konsolidasi vertikal dapat diketahui dari persamaan berikut:

$$
\begin{aligned}
& \mathrm{U}_{\mathrm{v}}=\sqrt{\frac{4 T_{v}}{\pi}} \\
& \mathrm{T}_{\mathrm{v}}=\frac{C v}{d^{2}} \mathrm{~T} \\
& \mathrm{~T}_{\mathrm{v}}=-0,933 \log \left(1-\mathrm{U}_{\mathrm{v}}\right)-0,085 \\
& \mathrm{~d}=\mathrm{H} \quad \text { untuk drainase } 1 \text { arah } \\
& \mathrm{d}=\frac{1}{2} \mathrm{H} \text { untuk drainase } 2 \text { arah }
\end{aligned}
$$

Derajat konsolidasi rata-rata kombinasi dari konsolidasi vertikal dan horizontal dapat diperoleh dari persamaan berikut (Walker dan Indraratna, 2006):

$$
\mathrm{U}=1-\left(1-\mathrm{U}_{\mathrm{h}}\right)\left(1-\mathrm{U}_{\mathrm{v}}\right)
$$

Batas penurunan timbunan (konsolidasi) pada penggunaan prefabricated vertical drains (PVD) minimum mencapai derajat konsolidasi 90\% atau sesuai persyaratan perancangan (SNI 8460:2017).

\section{Koefisien konsolidasi}

Koefisien konsolidasi berbanding terbalik dengan batas cair dari tanah. Semakin besar batas cair maka nilai koefisien konsolidasi akan semakin kecil. Nilai koefisien konsolidasi dapat ditentukan dengan dua metode, yaitu metode logaritma waktu yang diperkenalkan oleh Casagrande dan Fandum (1940) dan metode akar waktu yang diperkenalkan oleh Taylor (1942) yang dikutip dari Das (1995).

Untuk menghitung nilai koefisien konsolidasi dengan menggunakan metode logaritma waktu dapat digunakan persamaan berikut (Casagrande dan Fandum, 1940):

$$
\mathrm{C}_{\mathrm{v}}=\frac{0,197 H_{d r}^{2}}{t_{50}}
$$

Metode akar waktu yang diperkenalkan oleh Taylor (1942) menyarankan persamaan berikut untuk menghitung koefisien konsolidasi:

$$
\mathrm{C}_{\mathrm{v}}=\frac{0,848 H_{d r}^{2}}{t_{50}}
$$

\section{Data teknis pesawat terbang Airbus A380}

Pada penelitian ini digunakan infrastruktur berupa taxiway dengan beban berupa pesawat Airbus A380. Berat pesawat dibutuhkan untuk keperluan perencanaan tebal lapisan perkerasan lapangan terbang. Untuk merencanakan tebal lapis perkerasan pada bagian taxiway digunakan Maximum Taxi Weight (MTW). Data berat pesawat Airbus A380 dapat dilihat pada Tabel 3. dengan varian pesawat Airbus A380 yang digunakan yaitu WV011. 
Tabel 3. Berat pesawat Airbus A380-800 varian WV010 sampai dengan WV014

\begin{tabular}{|c|c|c|c|c|c|}
\hline \multicolumn{6}{|c|}{ Aircraft Characteristics } \\
\hline & WV010 & WV011 & WV012 & WV013 & WV014 \\
\hline $\begin{array}{l}\text { Maximum Ramp Weight (MRW) } \\
\text { Maximum Taxi Weight (MTW) }\end{array}$ & $\begin{array}{c}482000 \mathrm{~kg} \\
(1052628 \mathrm{lb})\end{array}$ & $\begin{array}{c}577000 \mathrm{~kg} \\
(1272067 \mathrm{lb})\end{array}$ & $\begin{array}{c}571000 \mathrm{~kg} \\
(1258839 \mathrm{lb})\end{array}$ & $\begin{array}{c}494000 \mathrm{~kg} \\
(1089083 \mathrm{lb})\end{array}$ & $\begin{array}{c}574000 \mathrm{~kg} \\
(1265453 \mathrm{lb})\end{array}$ \\
\hline $\begin{array}{l}\text { Maximum Take-Off Weight } \\
\text { (MTOW) }\end{array}$ & $\begin{array}{c}480000 \mathrm{~kg} \\
(1058219 \mathrm{lb})\end{array}$ & $\begin{array}{c}575000 \mathrm{~kg} \\
(1128658 \mathrm{lb})\end{array}$ & $\begin{array}{c}569000 \mathrm{~kg} \\
(1254430 \mathrm{lb})\end{array}$ & $\begin{array}{c}492000 \mathrm{~kg} \\
(1084674 \mathrm{lb})\end{array}$ & $\begin{array}{c}572000 \mathrm{~kg} \\
(1261044 \mathrm{lb})\end{array}$ \\
\hline $\begin{array}{l}\text { Maximum Landing Weight } \\
\text { (MLW) }\end{array}$ & $\begin{array}{c}388000 \mathrm{~kg} \\
(850984 \mathrm{lb})\end{array}$ & $\begin{array}{l}395000 \mathrm{~kg} \\
(870826 \mathrm{lb})\end{array}$ & $\begin{array}{l}395000 \mathrm{~kg} \\
(870826 \mathrm{lb})\end{array}$ & $\begin{array}{c}386000 \mathrm{~kg} \\
(850984 \mathrm{lb})\end{array}$ & $\begin{array}{c}391000 \mathrm{~kg} \\
(862007 \mathrm{lb})\end{array}$ \\
\hline $\begin{array}{l}\text { Maximum Zero Fuel Weight } \\
\text { (MZFW) }\end{array}$ & $\begin{array}{l}361000 \mathrm{~kg} \\
(795869 \mathrm{lb})\end{array}$ & $\begin{array}{l}369000 \mathrm{~kg} \\
(813506 \mathrm{lb})\end{array}$ & $\begin{array}{l}366000 \mathrm{~kg} \\
(806892 \mathrm{lb})\end{array}$ & $\begin{array}{l}361000 \mathrm{~kg} \\
(795869 \mathrm{lb})\end{array}$ & $\begin{array}{c}366000 \mathrm{~kg} \\
(806892 \mathrm{lb})\end{array}$ \\
\hline
\end{tabular}

(Sumber: Airbus S. A. S, 2005)

Untuk memperoleh beban yang diberikan oleh pesawat ke lapisan perkerasan, maka berat pesawat harus dibagi dengan luasan roda pesawat. Pesawat Airbus A380 memiliki tiga tipe roda yang terdiri dari noise gear, body gear, dan wing gear. Body gear dan wing gear yang digunakan untuk analisis karena distribusi beban kedua tipe roda tersebut lebih besar dari pada distribusi beban ke noise gear.

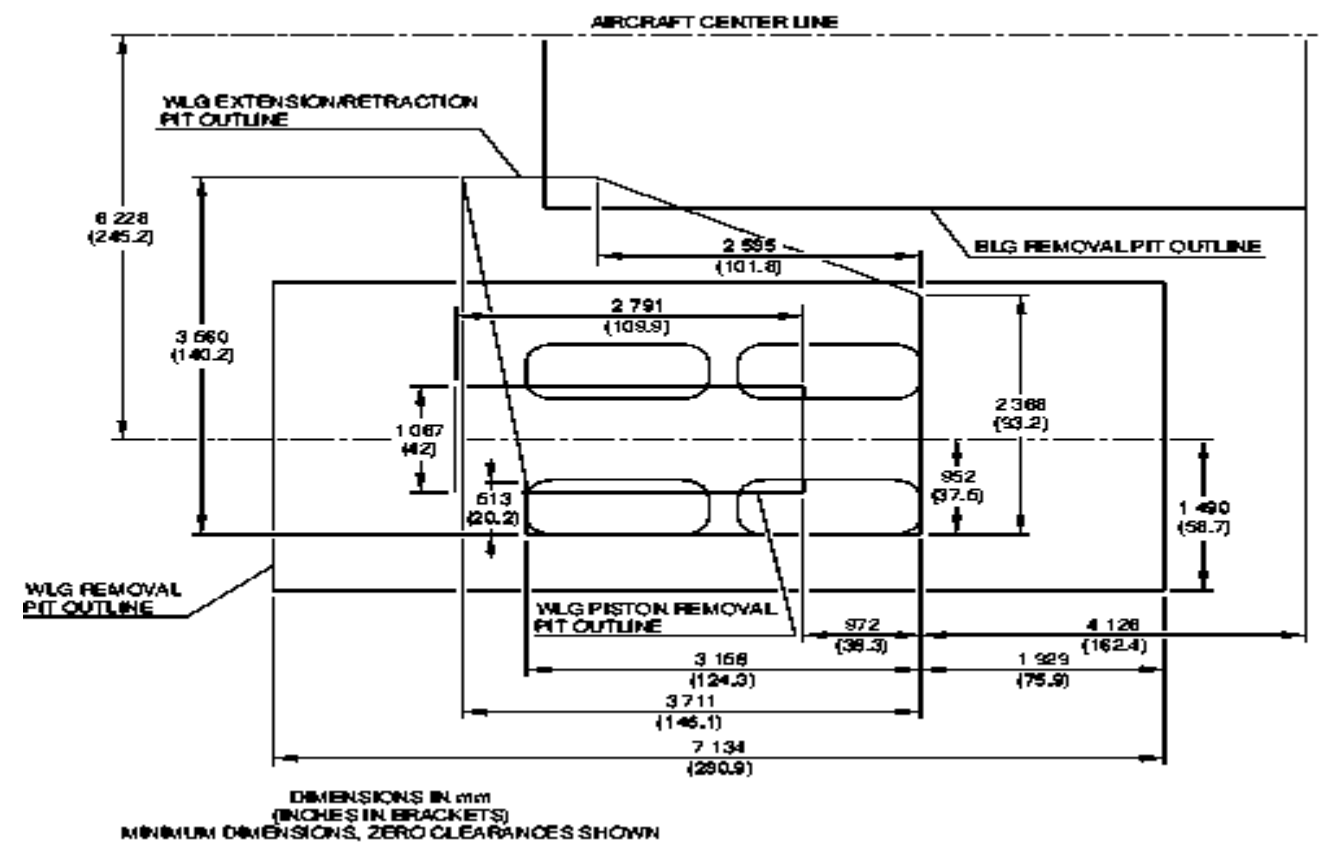

Gambar 6. Dimensi wing gears pesawat Airbus A380-800 (Sumber: Airbus S. A. S, 2005)

Pada Gambar 6. menunjukkan dimensi dari wing gear pesawat Airbus A380-800, wing gears terletak pada sayap pesawat. Dimensi dari body gear pesawat Airbus A380-800 pada Gambar 7., letak dari body gears yaitu pada bagian badan pesawat. 


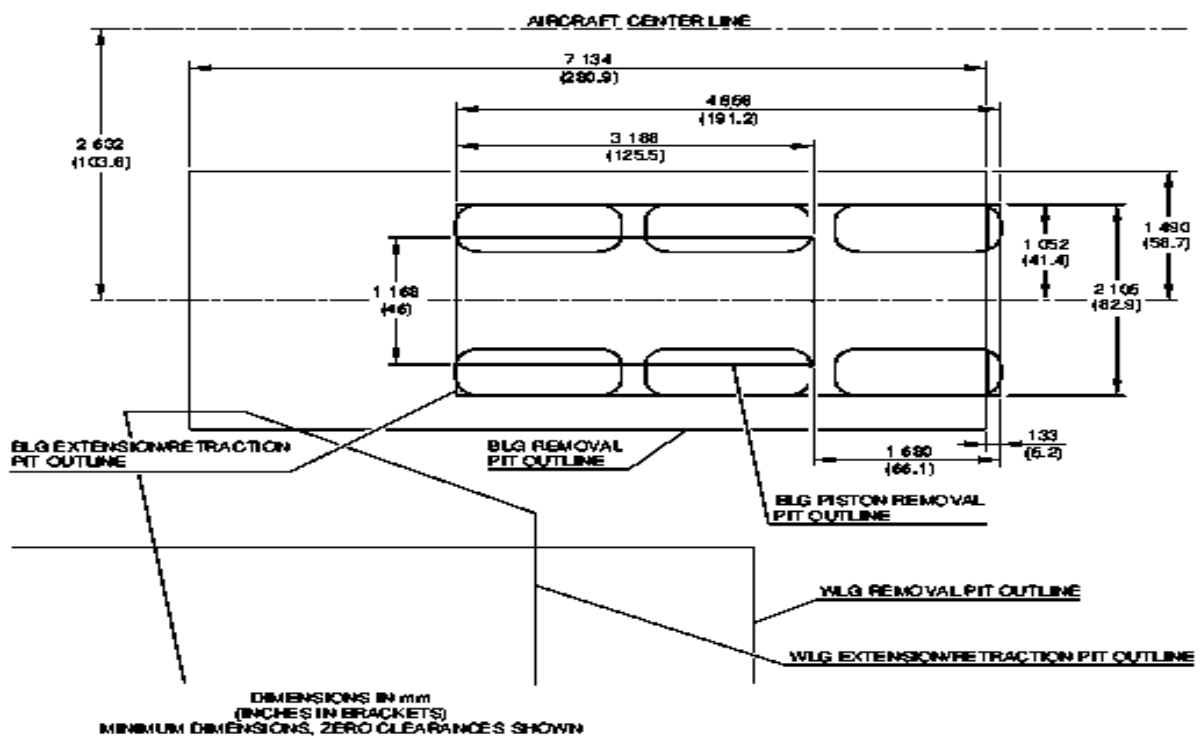

Gambar 7. Dimensi body gears pesawat Airbus A380-800 (Sumber: Airbus S. A. S, 2005)

\section{METODOLOGI PENELITIAN}

Penelitian ini dilakukan dengan cara mengumpulkan data tanah yang memiliki kondisi tanah kohesif lunak jenuh air dengan lapisan lensa. Selain data tanah, penulis juga mengumpulkan data pembebanan berupa data berat pesawat dan dimensi roda pesawat Airbus A380 serta memperoleh gambar potongan melintang taxiway Bandara Internasional Soekarno-Hatta untuk dilakukan analisis. Kemudian penulis membuat spreadsheet untuk membantu proses perhitungan. Setelah itu dilakukan perhitungan waktu dan besar penurunan konsolidasi yang terjadi dengan menggunakan spreadsheet yang telah dibuat. Setelah diperoleh hasil perhitungan, penulis menganalisis hasil perhitungan untuk diambil kesimpulan dari hasil penelitian yang telah dilakukan.

\section{Diagram alir penelitian}

Gambar 8 adalah diagram alir dari penelitian yang dilakukan yang menjelaskan tahap-tahap penelitian mulai dari pengumpulan data, analisis, hingga pengambilan kesimpulan.

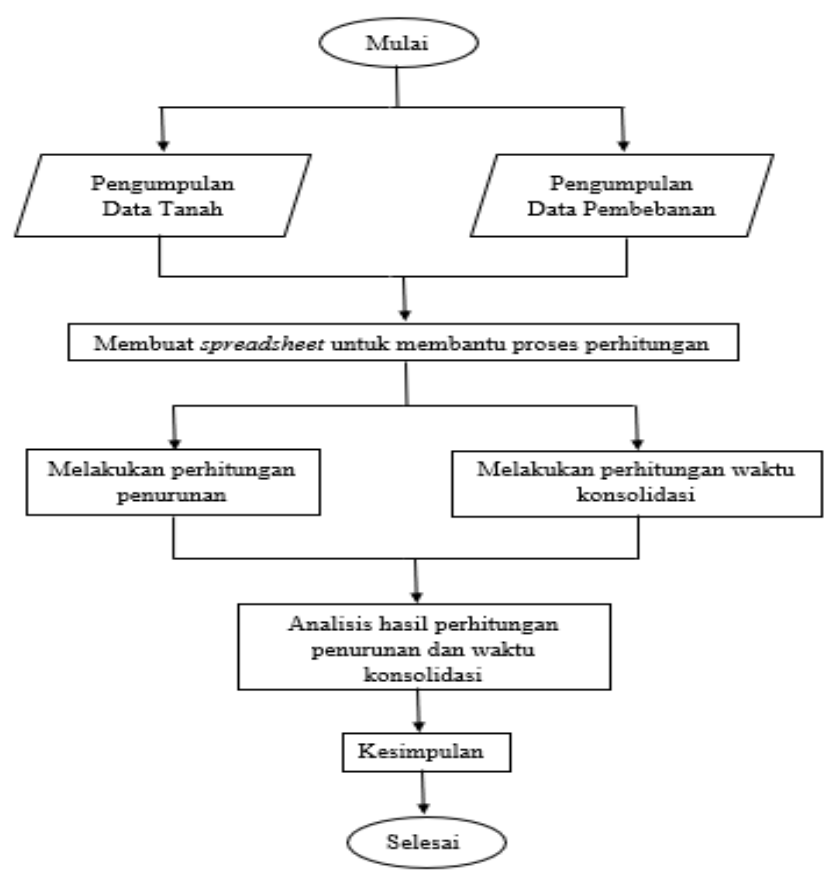

Gambar 8. Diagram alir penelitian 


\section{ANALISIS DAN PEMBAHASAN}

\section{Spesifikasi prefabricated vertical drains (PVD) yang digunakan}

Berikut ini merupakan spesifikasi PVD yang digunakan dalam penulisan skripsi ini. Spesifikasi teknis diambil dari suatu produk PVD.

Tabel 4. Data spesifikasi PVD

\begin{tabular}{cc}
\hline Kapasitas pengaliran & $\geq 100 \times 10^{-6} \mathrm{~m}^{3} /$ detik \\
Lebar & $100 \mathrm{~mm}$ \\
Tebal & $3 \mathrm{~mm}$ \\
Jarak antar PVD & $1 \mathrm{~m}$ \\
\hline
\end{tabular}

\section{Data tanah}

Pada penulisan skripsi ini digunakan data tanah di wilayah Kembangan, Jakarta Barat yang ditunjukkan pada Gambar 9.

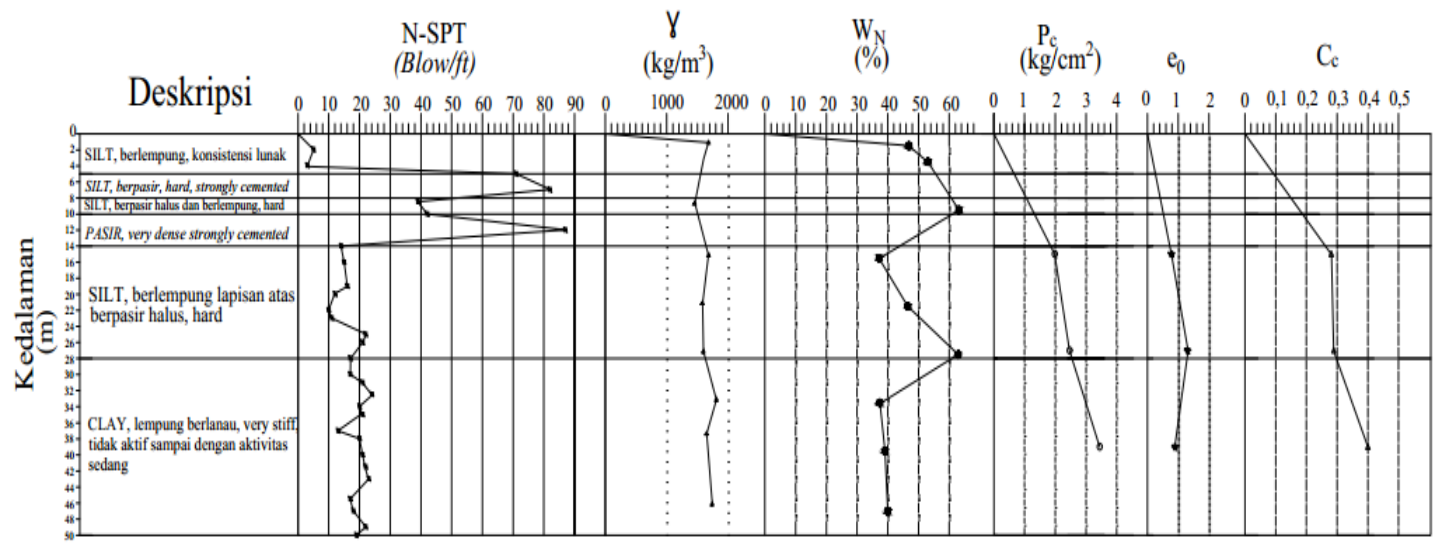

Gambar 9. Data tanah

\section{Potongan melintang taxiway}

Untuk pembebanan digunakan infrastruktur berupa taxiway Bandara Internasional Soekarno-Hatta. Potongan melintang dari taxiway dapat dilihat pada Gambar 10.

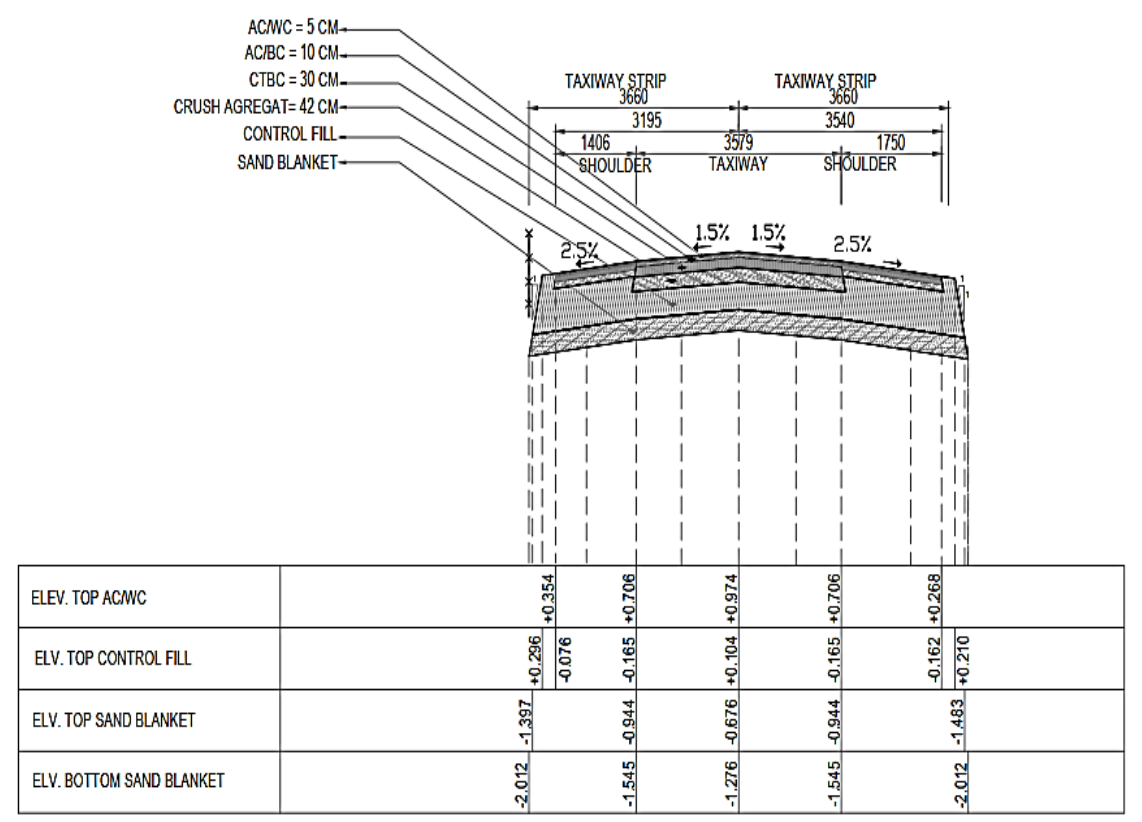

Gambar 10. Potongan melintang taxiway 


\section{Menentukan derajat konsolidasi}

Digunakan derajat konsolidasi horizontal sebesar 60\% dengan derajat konsolidasi rata-rata yang direncanakan sebesar 90\% sesuai dengan persyaratan yang diberikan pada SNI 8460:2017 tentang konsolidasi minimum penggunaan prefabricated vertical drains (PVD). Derajat konsolidasi horizontal rencana dan derajat konsolidasi rata-rata rencana diinput ke dalam spreadsheet seperti pada Tabel 5.

Tabel 5. Input parameter derajat konsolidasi di spreadsheet

\begin{tabular}{llll}
\hline Derajat konsolidasi rata-rata rencana & $(\mathrm{U})$ & 90 & $\%$ \\
Derajat konsolidasi horizontal rencana & $\left(\mathrm{U}_{\mathrm{h}}\right)$ & 60 & $\%$ \\
\hline
\end{tabular}

\section{Menentukan parameter prefabricated vertical drains (PVD)}

Tabel 6. Input parameter PVD di spreadsheet

\begin{tabular}{lrll}
\hline Lebar PVD (w) & 100 & $\mathrm{~mm}$ \\
Tebal PVD (t) & 3 & $\mathrm{~mm}$ \\
Jarak PVD (S) & 1 & $\mathrm{~m}$ \\
Discharge capacity $\quad\left(\mathrm{q}_{\mathrm{w}}\right)$ & 0,0001 & $\mathrm{~m}^{3} /$ detik \\
\hline
\end{tabular}

Input data parameter PVD di spreadsheet ditunjukkan seperti pada Tabel 6. Parameter yang diinput terdiri dari lebar dan tebal PVD, memilih pola PVD yang digunakan, jarak antar PVD, dan kapasitas pengaliran.

\section{Input data tanah}

Tanah dibagi menjadi beberapa lapisan, dalam menentukan lapisan tanah menggunakan acuan berdasarkan lapisan tanah di boring log, lapisan lensa, dan juga berdasarkan kedalaman muka air tanah untuk memudahkan input berat jenis efektif tanah dan parameter lainnya. Untuk berat jenis tanah yang diinput adalah berat jenis efektif tanah, data parameter tanah yang diinput ke dalam spreadsheet terdiri dari koefisien permeabilitas, angka pori awal, koefisien pemadatan tanah asli, koefisien pemadatan tanah yang telah dipadatkan, koefisien konsolidasi, berat jenis efektif, kadar air, dan tekanan pra konsolidasi.

Tabel 7. Input data tanah di spreadsheet

\begin{tabular}{ccccccccc}
\hline Lapisan Tanah & $\begin{array}{c}\text { Koefisien } \\
\text { Permeabilitas } \\
(\mathrm{cm} / \text { detik })\end{array}$ & $\mathrm{e}_{0}$ & $\begin{array}{c}\mathrm{C}_{\mathrm{c}} \text { Tanah } \\
\text { Asli }\end{array}$ & $\begin{array}{c}\mathrm{C}_{\mathrm{v}} \\
\left(\mathrm{cm}^{2} / \mathrm{menit}\right)\end{array}$ & $\begin{array}{c}\gamma^{\prime} \\
\left(\mathrm{kg} / \mathrm{m}^{3}\right)\end{array}$ & $\begin{array}{c}\mathrm{W}_{\mathrm{N}} \\
(\%)\end{array}$ & $\begin{array}{c}\mathrm{P}_{\mathrm{c}} \\
\left(\mathrm{kg} / \mathrm{cm}^{2}\right)\end{array}$ & $\begin{array}{c}\mathrm{C}_{\mathrm{C}} \\
\text { Tanah } \\
\text { Dipadatkan }\end{array}$ \\
\hline Lapisan ke-1 & 0,00001 & 0,782 & 0,281 & 0,0175 & 1681 & 53,05 & 1,98 & 0,19 \\
Lapisan ke-2 & 0,00001 & 0,782 & 0,281 & 0,0175 & 606 & 53,05 & 1,98 & 0,19 \\
Lapisan ke-3 & 0,00001 & 0,782 & 0,281 & 0,0175 & 461 & 63,16 & 1,98 & 0,19 \\
Lapisan ke-4 & 0,001 & 0,782 & 0,281 & 0,0175 & 461 & 37,21 & 1,98 & 0,19 \\
Lapisan ke-5 & 0,00001 & 1,305 & 0,289 & 0,015 & 682 & 46,52 & 2,46 & 0,19 \\
Lapisan ke-6 & 0,00001 & 1,305 & 0,289 & 0,015 & 584 & 62,89 & 2,46 & 0,19 \\
Lapisan ke-7 & 0,00001 & 1,305 & 0,289 & 0,015 & 600 & 62,89 & 2,46 & 0,19 \\
Lapisan ke-8 & 0,000001 & 0,899 & 0,4 & 0,0175 & 811 & 39,11 & 3,44 & 0,19 \\
Lapisan ke-9 & 0,000001 & 0,899 & 0,4 & 0,0175 & 653 & 39,55 & 3,44 & 0,19 \\
Lapisan ke-10 & 0,000001 & 0,899 & 0,4 & 0,0175 & 742 & 39,55 & 3,44 & 0,19 \\
\hline
\end{tabular}

\section{Menentukan dimensi dan berat timbunan}

Digunakan timbunan setinggi $3 \mathrm{~m}$ dengan lebar bagian bawah timbunan 12,5 $\mathrm{m}$ dan lebar bagian atas timbunan 6,5 $\mathrm{m}$. Timbunan berupa campuran lempung dengan pasir dengan komposisi $60 \%$ lempung dan $40 \%$ pasir, maka diperoleh berat jenis timbunan sebesar $1520 \mathrm{~kg} / \mathrm{m}^{3}$ dengan berat timbunan sebesar $43320 \mathrm{~kg} / \mathrm{m}$.

\section{Beban pesawat Airbus A380}

Digunakan pesawat Airbus A380 dengan karakteristik pesawat WV011 yang memiliki maximum taxi weight (MTW) sebesar $577000 \mathrm{~kg}$. Dari maximum taxi weight (MTW) yang telah diperoleh diplot pada grafik distribusi berat pesawat ke body gears dan wing gears seperti pada Gambar 14. 


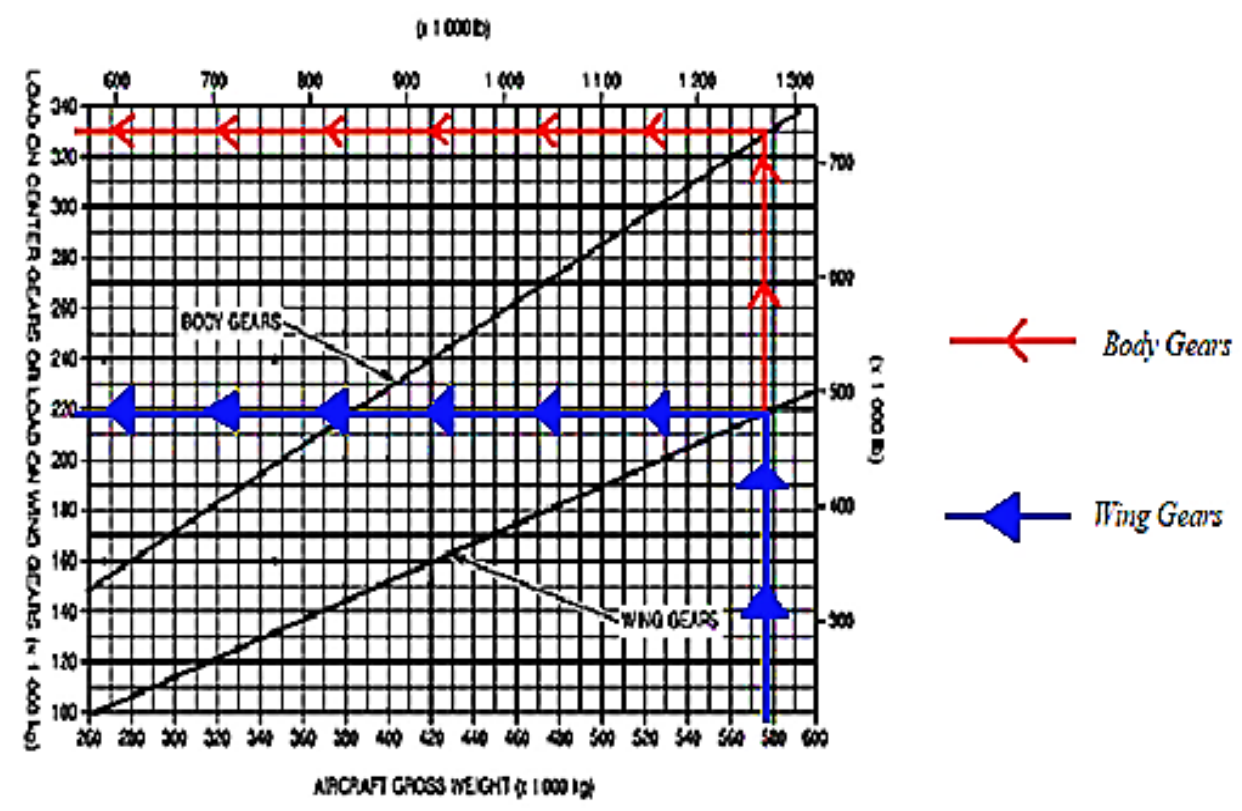

Gambar 11. Mencari distribusi berat pesawat ke wing gears dan body gears

Dari grafik diperoleh distribusi berat pesawat ke wing gears sebesar $219000 \mathrm{~kg}$ dan $330000 \mathrm{~kg}$ ke body gears. Berat tersebut merupakan berat yang diterima sepasang wing gears ataupun body gears. Oleh karena itu, berat pesawat yang diperoleh dari grafik harus dibagi 2 untuk mendapat berat yang diterima oleh satu wing gear ataupun body gear. Maka berat pesawat yang diterima oleh wing gear adalah $109500 \mathrm{~kg}$ dan berat pesawat yang diterima oleh body gear adalah $165000 \mathrm{~kg}$. Untuk mendapatkan tekanan yang diberikan roda pesawat ke lapisan perkerasan, berat pesawat yang diterima wing gear dan body gear harus dibagi luas area masing-masing.

Dari ukuran area wing gear dan body gear yang terdapat pada Gambar 6 dan Gambar 7 diperoleh luas area wing gear sebesar $6,01 \mathrm{~m}^{2}$ dan luas area body gear sebesar $10,25 \mathrm{~m}^{2}$. Diperoleh tekanan yang diberikan roda pesawat ke lapisan perkerasan sebesar $18219,63 \mathrm{~kg} / \mathrm{m}^{2}$ untuk wing gear dan $16144,81 \mathrm{~kg} / \mathrm{m}^{2}$ untuk body gear. Tekanan dari wing gear yang digunakan untuk analisis, karena tekanan dari wing gear lebih besar dari tekanan body gear.

\section{Distribusi tegangan pada lapisan perkerasan}

Tegangan dari roda pesawat disalurkan ke lapisan tanah dasar mengikuti pola garis penyebaran tegangan seperti pada Gambar 12. Kemiringan garis penyebaran tegangan lapisan AC/WC, AC/BC, dan CTBC sebesar 1:2. Sedangkan kemiringan garis penyebaran tegangan untuk lapisan batu pecah, pasir batu (sirtu), dan pasir sebesar 2:1.

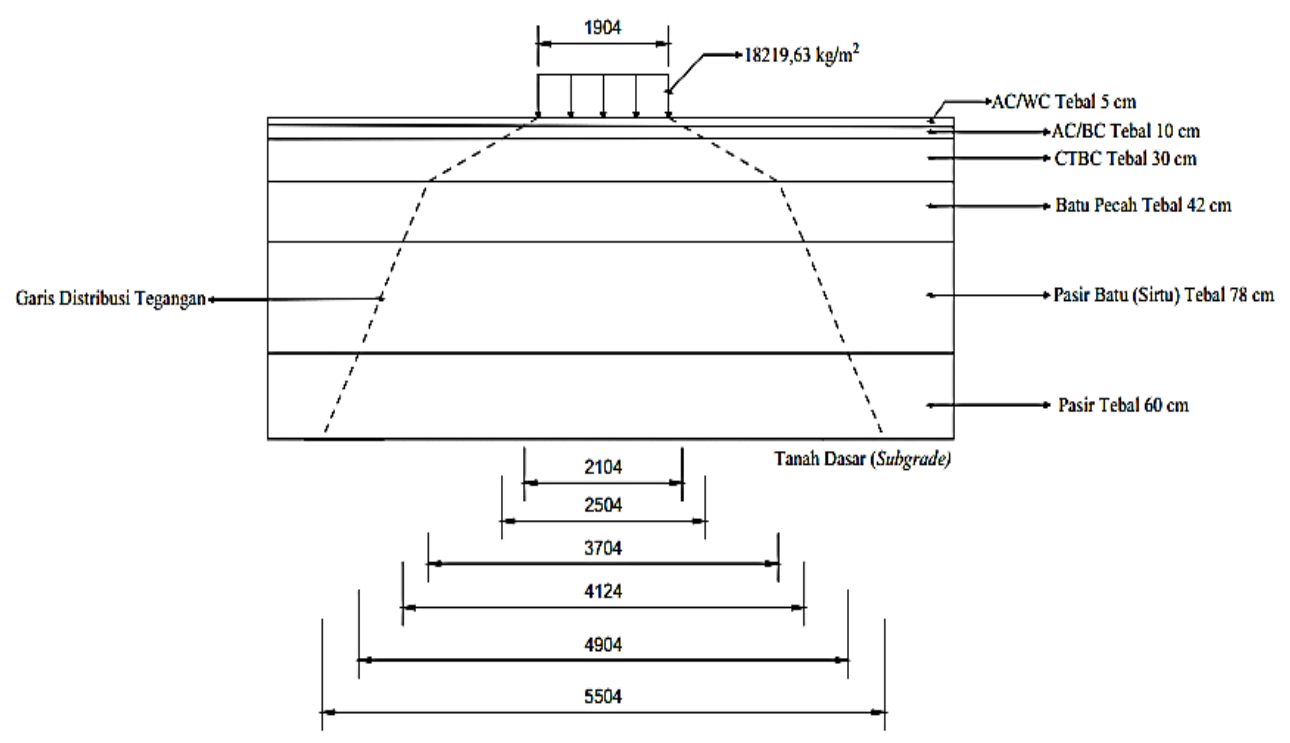

Gambar 12. Distribusi tegangan dari roda pesawat hingga tanah dasar 
Dari hasil perhitungan distribusi tegangan diperoleh tegangan yang berkerja pada tanah dasar (subgrade) sebesar $4732,97 \mathrm{~kg} / \mathrm{m}^{2}$. Data-data timbunan dan pembebanan seperti dimensi timbunan, berat jenis tanah timbunan, tegangan yang bekerja pada tanah dasar diinput ke dalam spreadsheet seperti pada Tabel 8.

Tabel 8. Input data timbunan dan pembebanan di spreadsheet

\begin{tabular}{lrl}
\hline Tinggi timbunan (h) & 3 & $\mathrm{~m}$ \\
Lebar bagian bawah timbunan (B) & 12,5 & $\mathrm{~m}$ \\
Lebar bagian atas timbunan (b) & 6,5 & $\mathrm{~m}$ \\
У timbunan & 1520 & $\mathrm{~kg} / \mathrm{m}^{3}$ \\
Beban yang berkerja & 7104,5 & $\mathrm{~kg} / \mathrm{m}^{2}$ \\
\hline
\end{tabular}

\section{Diameter pengaruh prefabricated vertical drains (PVD)}

Diameter pengaruh PVD dipengaruhi oleh jarak antar PVD dan pola pemasangan PVD. Pada penulisan skripsi ini digunakan jarak antar PVD sebesar $1 \mathrm{~m}$ diperoleh diameter pengaruh PVD sebesar 1,128 m untuk pemasangan PVD pola persegi dan sebesar 1,05 $\mathrm{m}$ untuk pola segitiga.

\section{Diameter ekivalen prefabricated vertical drains (PVD)}

Digunakan persamaan dari Long dan Covo (1994) untuk menghitung diameter ekivalen PVD. Diameter ekivalen dipengaruhi oleh tebal dan lebar penampang PVD yang digunakan. Penampang PVD yang digunakan memiliki tebal $3 \mathrm{~mm}$ dengan lebar $100 \mathrm{~mm}$. Dengan ukuran penampang tersebut diperoleh diameter ekivalen PVD sebesar 52,1 $\mathrm{mm}$.

\section{Diameter smear zone}

Menurut persamaan yang diberikan Hansbo (1997), nilai diameter smear zone berkisar antara 1,5 sampai 3 kali dari diameter ekivalen PVD. Pada penulisan skripsi ini digunakan diameter smear zone sebesar 2 kali diameter ekivalen PVD. Dari hasil perhitungan diperoleh diameter smear zone sebesar 104,2 mm.

\section{Rasio diameter pengaruh dengan diameter ekivalen prefabricated vertical drains (PVD)}

Rasio diameter pengaruh dengan diameter ekivalen PVD sebesar 21,65 untuk pola persegi dan sebesar 20,15 untuk pola segitiga yang diperoleh dari perbandingan antara diameter pengaruh sebesar $112,80 \mathrm{~cm}$ untuk pola persegi dan $105 \mathrm{~cm}$ untuk pola segitiga dengan diameter ekivalen PVD sebesar 5,21 cm.

\section{Rasio diameter ekivalen smear zone dengan diameter ekivalen prefabricated vertical drains (PVD)}

Rasio diameter ekivalen smear zone dengan diameter ekivalen PVD sebesar 2 yang diperoleh dari perbandingan antara diameter ekivalen smear zone sebesar 10,42 cm dengan diameter ekivalen PVD sebesar 5,21 cm.

\section{Hasil perhitungan waktu dan besar penurunan}

Berikut ini merupakan hasil perhitungan waktu dan besar penurunan yang disajikan pada Tabel 9. Dari tabel tersebut dapat dilihat besar penurunan pra-pembebanan maksimum sebesar 234,80 cm dengan waktu penurunan selama 2260 hari untuk pola persegi dan selama 1918 hari untuk pola segitiga serta penurunan pasca pembebanan sebesar $2,5 \mathrm{~cm}$ pada pemasangan prefabricated vertical drains (PVD) untuk kedalaman $50 \mathrm{~m}$.

Tabel 9. Hasil perhitungan waktu dan besar penurunan

\begin{tabular}{|c|c|c|c|c|}
\hline \multirow{3}{*}{$\begin{array}{c}\text { Panjang } \\
\text { PVD } \\
\text { (m) }\end{array}$} & \multicolumn{2}{|c|}{ Waktu (hari) } & \multicolumn{2}{|c|}{ Penurunan $(\mathrm{cm})$} \\
\hline & Pola & Pola & Pra & Pasca \\
\hline & Persegi & Segitiga & Pembebanan & Pembebanan \\
\hline 3,7 & 215 & 183 & 19,9 & 51,3 \\
\hline 5 & 430 & 365 & 26,6 & 49,0 \\
\hline 10 & 644 & 548 & 74,6 & 42,7 \\
\hline 14 & 859 & 730 & 111,1 & 42,0 \\
\hline 19 & 1113 & 944 & 125,9 & 42,5 \\
\hline 24 & 1364 & 1157 & 140,2 & 38,5 \\
\hline 28 & 1615 & 1370 & 151,5 & 34,4 \\
\hline 36 & 1830 & 1553 & 182,4 & 28,4 \\
\hline 44 & 2045 & 1735 & 212,5 & 13,1 \\
\hline 50 & 2260 & 1918 & 234,8 & 2,5 \\
\hline
\end{tabular}




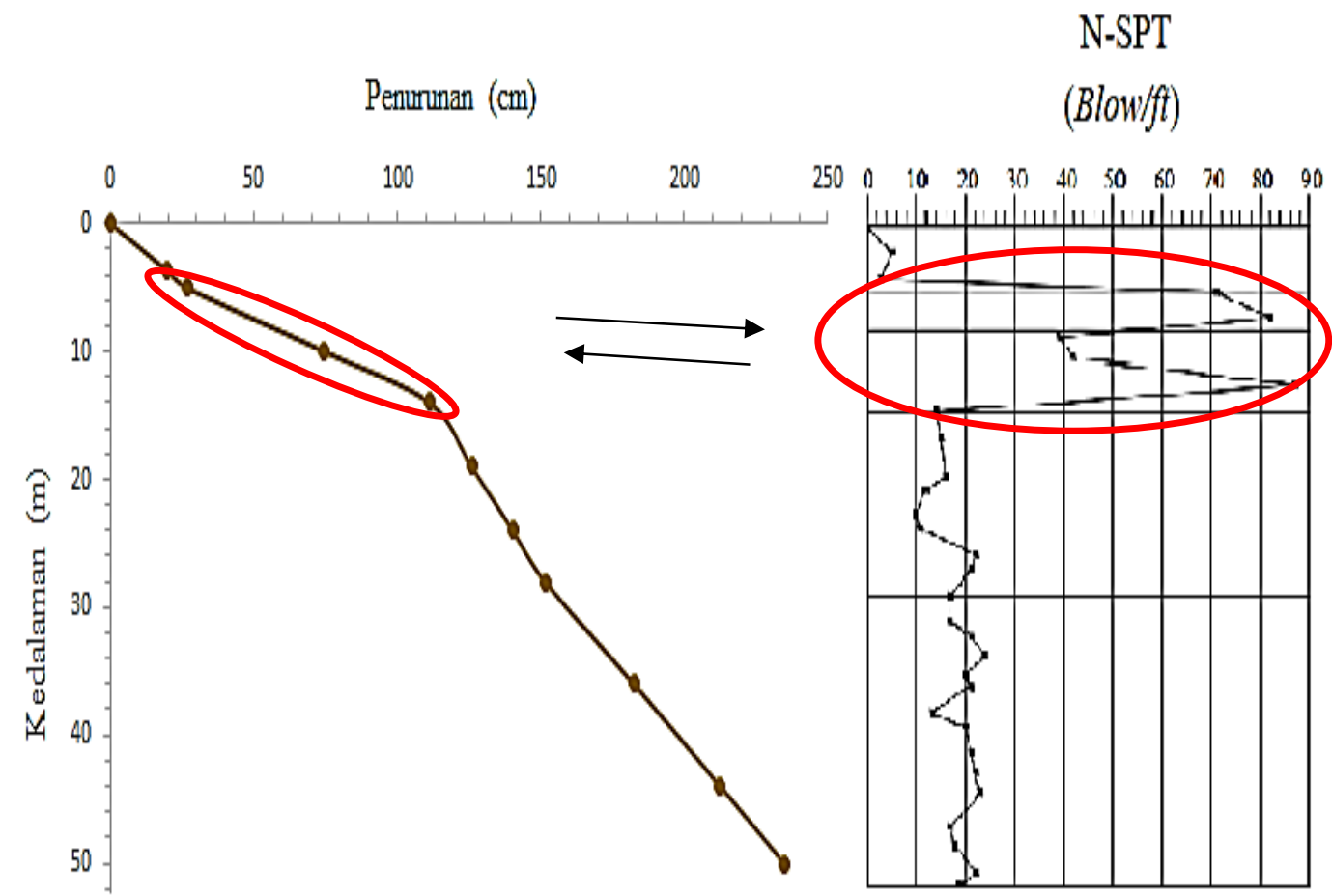

Gambar 13. Grafik penurunan pada tahap pra-pembebanan terhadap kedalaman pemasangan PVD

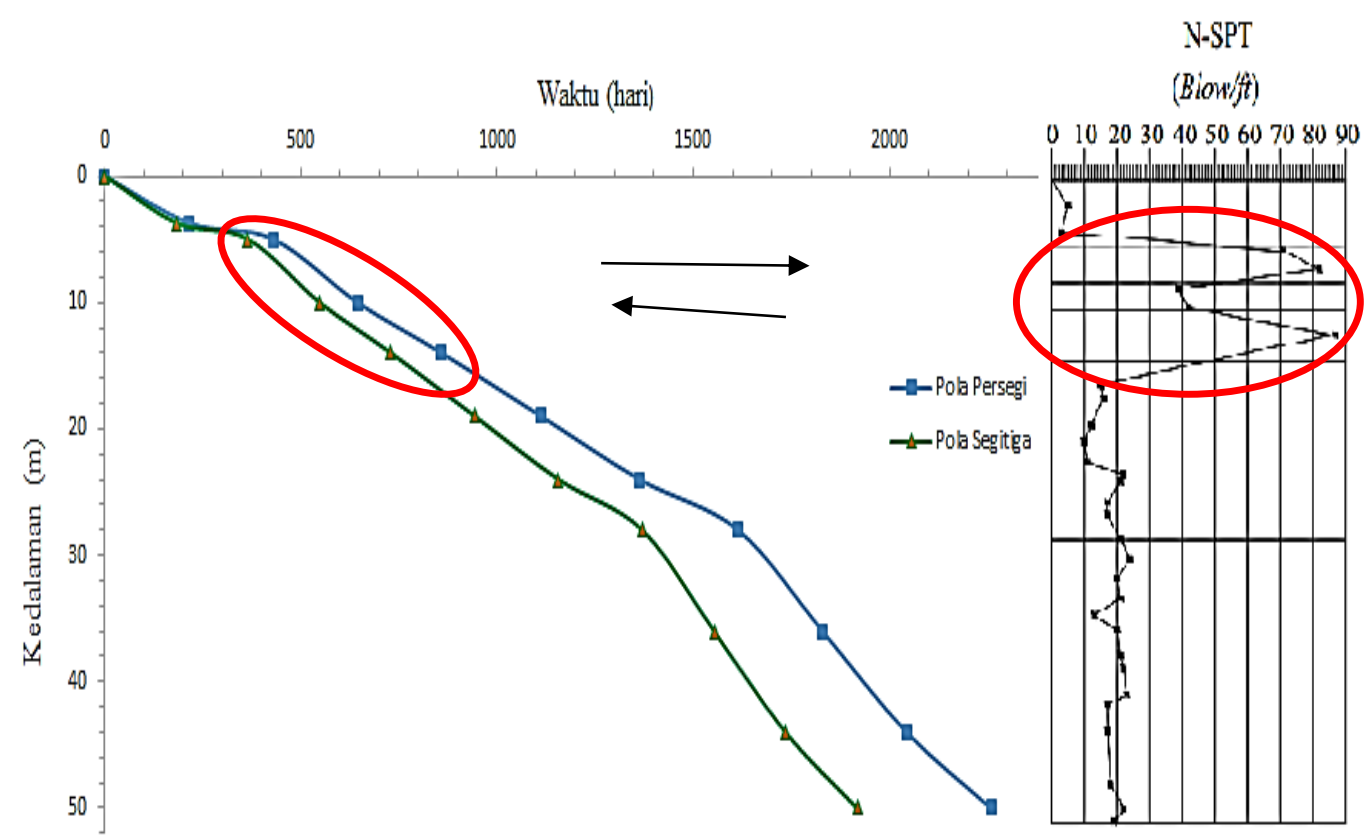

Gambar 14. Grafik waktu penurunan terhadap kedalaman pemasangan PVD 


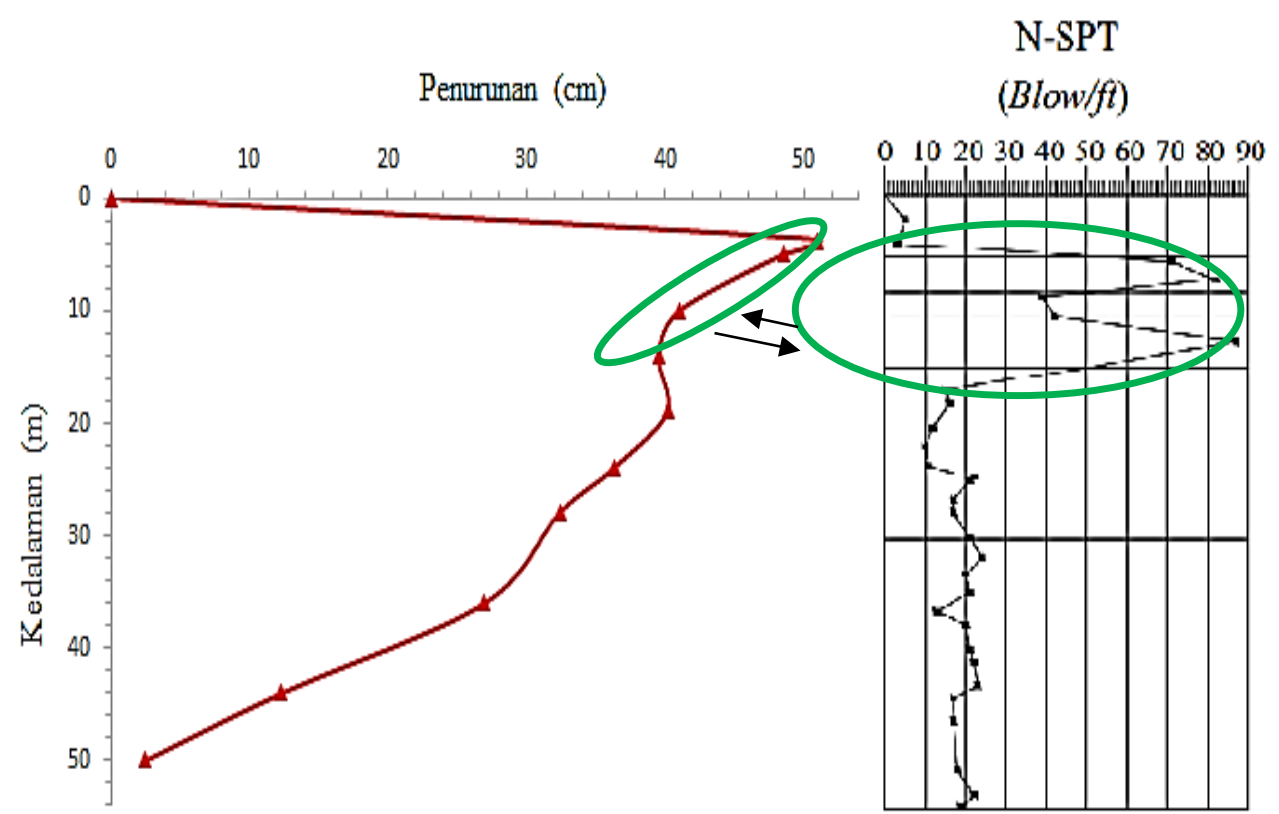

Gambar 15. Grafik penurunan pasca pembebanan terhadap kedalaman pemasangan PVD

\section{KESIMPULAN DAN SARAN}

\section{Kesimpulan}

Dari hasil analisis dan pembahasan yang telah dilakukan, maka diperoleh beberapa kesimpulan sebagai berikut:

1. Kedalaman efektif pemasangan prefabricated vertical drains (PVD) adalah $50 \mathrm{~m}$. Pada kedalaman tersebut dapat dicapai penurunan pasca pembebanan sebesar 2,5 $\mathrm{cm}$ seperti pada Gambar 15.

2. Untuk pemasangan PVD pada kedalaman $50 \mathrm{~m}$ dibutuhkan waktu penurunan selama 2260 hari untuk pola persegi dan selama 1918 hari untuk pola segitiga yang diperoleh dari grafik hubungan waktu penurunan terhadap kedalaman pemasangan PVD pada Gambar 14.

3. Waktu penurunan pada pemasangan PVD pola segitiga hanya membutuhkan $80 \%$ dari waktu penurunan pada pola persegi seperti pada Tabel 9. Hal ini membuktikan pemasangan PVD pola segitiga lebih efektif dibandingkan pola persegi.

4. Laju penurunan pra pembebanan rata-rata pada lapisan lensa sekitar $0,19 \mathrm{~cm} / \mathrm{hari}$ untuk pola persegi dan sekitar $0,23 \mathrm{~cm} /$ hari untuk pola segitiga. Sedangkan untuk laju penurunan pra pembebanan rata-rata pada lapisan tanah yang berada di atas lapisan lensa sekitar $0,06 \mathrm{~cm} /$ hari untuk pola persegi dan sekitar $0,07 \mathrm{~cm} / \mathrm{hari}$ untuk pola segitiga, serta laju penurunan pra pembebanan rata-rata pada lapisan tanah yang berada di bawah lapisan lensa sekitar $0,10 \mathrm{~cm} /$ hari untuk pola persegi dan sekitar $0,11 \mathrm{~cm} /$ hari untuk pola segitiga. Angka laju penurunan diperoleh dari hasil perbandingan antara selisih penurunan dengan selisih waktu penurunan pada Tabel 9.

5. Penurunan pasca pembebanan pada lapisan lensa berkurang hingga $42 \mathrm{~cm}$ kemudian kembali meningkat hingga mencapai $42,5 \mathrm{~cm}$ pada kedalaman $19 \mathrm{~m}$ dan kembali berkurang hingga mencapai $2,5 \mathrm{~cm}$ pada kedalaman $50 \mathrm{~m}$ seperti pada grafik hubungan kedalaman pemasangan PVD terhadap penurunan pasca pembebanan yang terdapat pada Gambar 15 .

6. Pemasangan PVD pada lapisan lensa dibutuhkan waktu konsolidasi rata-rata 52 hari untuk setiap 1 meter kedalaman PVD sedangkan untuk pemasangan PVD pada lapisan tanah yang berada di bawah lapisan lensa dibutuhkan waktu konsolidasi rata-rata 30 hari untuk setiap 1 meter kedalaman PVD.

Dengan penggunaan PVD sedalam $50 \mathrm{~m}$, maka tanah dengan kondisi seperti pada penelitian ini dapat dibangun landasan terbang dengan pesawat rencana Airbus A380 ataupun sejenisnya. Hal ini dapat diaplikasikan di Indonesia sehingga dapat meningkatkan aksesibilitas terutama bagi wisatawan asing, karena mayoritas pesawat terbang yang melayani rute antar negara menggunakan pesawat berbadan lebar seperti Airbus A380 dan sejenisnya.

\section{Saran}

Untuk penelitian yang lebih lanjut, penulis memberikan beberapa saran sebagai berikut: 
1. Untuk memperoleh waktu penurunan yang lebih cepat, pada penelitian selanjutnya disarankan menggunakan jarak antar PVD kurang dari $1 \mathrm{~m}$.

2. Pada penelitian ini penulis menggunakan tinggi timbunan sebesar $3 \mathrm{~m}$ dan memperoleh besar penurunan pra pembebanan sebesar $234,80 \mathrm{~cm}$. Penelitian selanjutnya disarankan menggunakan timbunan lebih tinggi dari 3 $\mathrm{m}$ agar diperoleh penurunan pra pembebanan yang lebih besar.

3. Menggunakan metode lain yang dapat mempercepat waktu penurunan seperti metode vacuum preloading, dikombinasikan dengan metode dynamic compaction pada timbunan atau tanah timbunan digiling menggunakan sheep foot roller.

\section{DAFTAR PUSTAKA}

Airbus S.A.S. Customer Service Technical Data Support and Services, A380 Aircraft Characteristics Airport and Maintenance Planning. Airbus S.A.S., 2005.

Aspar, Wimpie, A. N., dan Eka N. Fitriani, "Pengaruh Jarak dan Pola Prefabricated Vertical Drain (PVD) Pada Perbaikan Tanah Lempung Lunak". Makalah Ilmiah Pengkajian Industri, vol. 10, no. 1, 2016, pp. 41-50.

Baron., R. A. "Consolidation of Fined-grained Soils by Drain Wells". Transactions of the American Society of Civil Engineers, vol. 113, no. 1, 1948, pp. 718-742.

Cai, A. S. Balasubramaniam H., Zhu, D., Surarak, C., dan Oh, E. Y. N. "Settlements of Embankments In Soft Soils”. Geothecnical Engineering Journal of SEAGS \& AGSSEA, vol. 41, no. 2, 2010, pp. 1-19.

Vertical Drains. 25 Agustus 2019: cofra.com/solutions/consolidation/vertical-drains.html.

Das, Braja M. Mekanika Tanah (Prinsip-prinsip Rekayasa Geoteknis). ed 2, Jakarta: Erlangga, 1995.

Hansbo, S. "Consolidation of Clay by Band-Shaped Prefabricated Drains". Ground Engineering, vol. 12, no. 5, 1979, pp. 16-27.

Hansbo, S. "Consolidation of Fine-graned Soils by Prefabricated Drains", Proceedings of 10th International Conference on Soil Mechanics and Foundation Engineering, Stockholm, vol. 3, 1981, pp. 677-682.

Hausmann, Manfred R., Engineering Principles of Ground Modification. McGraw-Hill, 1990.

Holtz, R. D., et al, Laboratory Testing of Prefabricated “Wick” Drains. Butterworth Heinemann, 1991

Long, Richard. P., dan Alvaro Covo. "Equivalent Diameter of Vertical Drains with an Oblong Cross Section." Journal of Geotechnical Engineering, vol. 120, no. 9, 1994, pp. 1625-1630.

Shen, Shui-Long., et al. "Analysis of Field Performance of Embankments on Soft Clay Deposit with and without PVD-Improvement”. Geotextiles and Geomembranes, vol. 23, no. 6, 2005, pp. 463-485.

Badan Standarisasi Nasional. SNI 8460:2017, Persyaratan Perancangan Geoteknik. Jakarta: Badan Standardisasi Nasional, 2017.

Terzaghi, Karl. dan Peck, Ralph B. Mekanika Tanah Dalam Praktek Rekayasa. Ed 2, Jakarta: Erlangga, 1967.

Walker, Rohan., dan Buddhima Indraratna. "Vertical Drain Consolidation with Parabolic Distribution of Permeability in Smear Zone”. Journal of Geotechnical and Geoenvironmental Engineering, vol. 132, no. 7, 2006, pp. 937-941. 
Analisis Penggunaan Prefabricated Vertical Drains (PVD)

Andreyan Prasetio, et al.

pada Tanah Lempung Lunak yang Terdapat Lapisan Lensa 